\title{
Structure of Revenue and Expenditure of Fishermen Household In South Kaur Subdistrict Kaur District
}

\author{
Bambang Sumantri, Melli Suryanty and Reki Susanti \\ Department of Agriculture Socio-Economic, Faculty of Agriculture, University of Bengkulu \\ Corresponding Author:: bsumantri@yahoo.com
}

\begin{abstract}
This study aims to determine the structure of fishermen household income and expenditure. This research was conducted in March-April 2018 in Sekunyit Village. Research location is determined by purposive with Sekunyit consideration that in the village is one of the fishing villages in the district portrait Kaur. Data processed using analysis of receipts and expenditures of households. The results showed the average amount of fisherman household income in Sekunyit Village was Rp. 8,606,594,59 / month. Revenue from the capture fisheries sector contributed the most $(82.08 \%)$ to the fishermen household income. Meanwhile, the average expenditure of a fisherman's household in Sekunyit Village is Rp. 3,980,499 / month, where 69.24\% was used to finance the capture fisheries business sector.
\end{abstract}

Key words: Revenue, Expenditures, Fisherman Households

Reference to this paper should be made as follows :

Sumantri, B. M. Suryanty and R. Susanti. 2019. Structure of revenue and expenditure of fishermen household in South Kaur Subdistrict Kaur District. Agritropica: Journal of Agricultural Science. 2(2):77-85. Doi: https://doi.org/10.31186/Jagritropica.2.2.77-85

\section{INTRODUCTION}

Bengkulu Province is one of the areas where the majority of the population works as fishermen because most of Bengkulu is a coastal area. One of the coastal areas in Bengkulu Province is Kaur Regency. Kaur Regency has considerable potential in its marine sector. Therefore, the majority of the residents' livelihoods are as fishermen.

Sekunyit Village is a portrait of a fishing village in Kaur Regency. This village became one of the suppliers of fishery production in the South Kaur District. As is the case with households in general, the structure of the reception of fisherman households in Sekunyit Village is sourced from its main occupation as capture fisheries. However, fishing activities for fishermen are very dependent on weather and season factors. At certain times, fishermen often can not go to sea because it is constrained by bad weather, high waves or natural obstacles that can not be conditioned.

To continue to be able to meet household needs, fishermen generally have side jobs as an alternative source of income for their households. These side jobs can take the form of trading, drivers, motorcycle taxi drivers, construction workers, or farm laborers. For those who own farming land, they can work in the agriculture or plantation sector. But for fishermen who do not have farming land, generally choose to participate in the service sector.

In addition to the reasons for dependence on weather conditions, the high necessities of life that must be met by households also encourage fishermen to have various sources of income. Therefore, the source of income of fishermen households can come from the capture fisheries business sector, nonfisheries sector, or from other sectors 
outside the agricultural sector.

The entire revenue that the fishermen in the end used to finance all the household expensesof his, such as expenditures of food, education, health, and other purposes. Expenditures for fishery business also must be spent fishing, such as repairing nets, treatment vessel and gear, fishing fees and the cost of feed. Therefore, in generals structures are at expenditure in households of fishermen can be grouped into the fisheries sector spending, spending nonfisheries sector, and non-agricultural expenditure. The distribution of fishermen household expenditure for each sector of expenditure will produce an interesting distribution pattern of expenditure to be studied. This study specifically aims to analyze the structure of income and expenditure of fishermen households and analyze the distribution of each component making up the structure of income and expenditure in fishermen households in Sekunyit Village.

\section{METHOD}

Determination of the location in this study was conducted purposively, namely in Desa Sekunyit, Kaur Selatan District, Kaur Regency. This location was chosen based on the consideration that almost $75 \%$ of the villagers work as fishermen. This research was conducted in during March-April 2018.

The population of this research is fisherman household. Not all populations are used as respondents. Determination of the number of research samples using the Slovin formula in order to obtain 74 fishing households that were respondents of the study. Fisherman households selected as respondents are then randomized using the lottery. Revenue analysis is carried out by describing the description of the structure of fishermen's revenue based on the sources of basic income and side income of fishermen's household (Soekartawi, 2003) The same formulation was used by Fatma A K and Sudrajat (2012), Mawardati. 2015, Tarigan, et al (2013), Kustiawati et al (2015), Putri, E.A., et al (2015), Zargustin, et al (2015) and Fauziyah (2010). This formulation by Manalu, (2018) was modified to be the calculation of fisherman household income. Formulated as follows:

$$
\sum \mathrm{TR}=\sum_{i=1}^{n} T R_{S I}+\sum_{i=1}^{m} T R_{S N I}+\sum_{i=1}^{p} T R_{S N P}
$$

$\sum \mathrm{TR}=$ Total revenue $(\mathrm{Rp} / \mathrm{month})$

SI $\quad=$ Total Fisheries sector revenue $(\mathrm{Rp} /$ month)

SNI = Total non-fisheries agriculture sector revenue ( $\mathrm{Rp} /$ month)

$\mathrm{SNP}=$ Total non-agricultural sector revenue (Rp / month)

$\mathrm{I}=1 \ldots \mathrm{n}=$ Types of fish receipts $(\mathrm{Rp} / \mathrm{month})$

$\mathrm{J}=1 \ldots \mathrm{m}=$ Non-fisheries agriculture sector revenue ( $\mathrm{Rp} /$ month)

$\mathrm{K}=1 \ldots \mathrm{p}=$ Non-agricultural sector revenue $(\mathrm{Rp}$ / month)

Analysis of household expenditures fishing is done by decomposing in the description of the structure of household expenditure based on kinds of expenses, spending the fisheries sector, the agricultural sector and the non-fisheries non fisheries sector. The following is the formulation of the equation:

$$
\sum \mathrm{TC}=\sum_{i=1}^{n} T C_{S I}+\sum_{i=1}^{m} T C_{S N I}+\sum_{i=1}^{p} T C_{S N P}
$$

$\sum \mathrm{TR}=$ Total expenditure $(\mathrm{Rp} /$ month $)$

$\mathrm{SI}=$ total fisheries sector expenditure (Rp / month)

$\mathrm{SNI}=$ Total expenditure for non-fisheries agriculture sector ( $\mathrm{Rp} /$ month)

$\mathrm{SNP}=$ Total non-agricultural sector expenditure ( $\mathrm{Rp} /$ month)

$\mathrm{I}=1 \ldots \mathrm{n}=$ Expenditures for tool 
depreciation + variable costs $(\mathrm{Rp} /$ month)

$\mathrm{J}=1 \ldots \mathrm{m}=$ Non-fisheries agriculture sector expenditure ( $\mathrm{Rp} /$ month)

$\mathrm{K}=1 \ldots . \mathrm{p}=$ Non-agricultural sector expenditure (Rp / month)

Next to analyze the distribution of each component making up the structure of revenue and expenditure in fishermen households used a descriptive approach using a distribution table.

\section{RESULTS AND DISCUSSION}

\section{Fisheries Household Acceptance \\ Structure}

\section{Revenue from the Fisheries Sector}

Revenue from the fisheries sector is revenue from fishing. This revenue is obtained from the production of types of fish and then multiplied by the selling price per type of fish. Fisheries sector revenue is determined by the large amount of production and the high and low price of fish per $\mathrm{kg}$.

Based on Table 1, the average amount of revenue from the fishery sector in Sekunyit village is Rp. 7,064,702,70.-. Revenue is quite high because at the time of the study the condition of the weather is good enough so that Fisherman can fishing every day. The frequency of fishing at sea if in good weather conditions is an average of 24 times per month. However, if the weather is bad, fishermen can only sail 12 times and sometimes fishermen cannot go to sea at all. Therefore, the fishermen's acceptance depends very much on the weather, price and catch production. Acceptance of fishermen in Sekunyit Village when compared with Dwi et al, (2016) research is still relatively low. Dwi et al, (2016) in his research in the Belitung area concluded that the average monthly fishing revenue could reach $\mathrm{Rp}$. 11,531,255.

Table 1. Fisheries Sector Revenue in March-April 2018

\begin{tabular}{clcc}
\hline No & \multicolumn{1}{c}{ Description } & Average (Rp) & Percentage (\%) \\
\hline 1 & Crow & $431,621.62$ & 6.11 \\
2 & Pari & $52,878.38$ & 0.75 \\
3 & Jenehe & $748,108.11$ & 10.59 \\
4 & Gebur & $714,594.59$ & 10.11 \\
5 & Rivet & $507,432.43$ & 7.18 \\
6 & Mackerel & $451,891.89$ & 6.4 \\
7 & Geez & $486,891.89$ & 6.89 \\
8 & Belide & $149,189.19$ & 2.11 \\
9 & Courtesy & $838,378.38$ & 11.87 \\
10 & Ruwan & $107,432.43$ & 1.52 \\
11 & Uncommon Teeth & $308,108.11$ & 4.36 \\
12 & Haur-haur & $357,094.59$ & 5.05 \\
13 & Simbe & $419,189.19$ & 5.93 \\
14 & A bag & $396,216.22$ & 5.61 \\
15 & Grouper & $532,972.97$ & 7.54 \\
16 & Big brother & 562.702 .70 & 7.96 \\
\hline \multicolumn{2}{c}{ total } & $\mathbf{7 , 0 6 4 , 7 0 2 . 7 0}$ & $\mathbf{1 0 0}$ \\
\hline
\end{tabular}

Source: Primary Data Processed, 2018 


\section{Non Fisheries Sector Revenue}

Aside from going to sea, a number of fishermen in Sekunyit Village also work in the agricultural sector, namely in the paddy farming. Farming lowland rice is only managed once a year. This is because the developed paddy rice farming only relies on rain-fed water sources. Therefore, the acceptance received from this paddy farming is not too large. Value of revenues generated amounted to Rp. $750,000.00$ per planting season with an average production of $264 \mathrm{~kg}$.

\section{Non-Agricultural Sector Revenue}

Non-agricultural sector revenue is a side income received by fisherman households. Non-agricultural revenues can be seen in detail in Table 2 .

Table 2. Non-Agriculture Sector Revenue in Sekunyit Village

\begin{tabular}{clcc}
\hline No & Description & Average (Rp) & Percentage (\%) \\
\hline 1 & Entrepreneur & $81,081.08$ & 20.15 \\
2 & Coolie & $18,378.38$ & 4.57 \\
3 & Honor & $55,405.41$ & 13.77 \\
4 & Employee & $62,162.16$ & $15: 45$ \\
5 & Shop & $31,756.76$ & 7.89 \\
6 & Private & $128,378.38$ & 31.91 \\
7 & Labor & $25,202.70$ & 6.26 \\
\hline & total & $\mathbf{7 9 1 , 8 9 1 . 8 9}$ & $\mathbf{1 0 0}$ \\
\hline
\end{tabular}

Source: Primary Data Processed, 2018

The non-farm fishermen household income in Sekunyit Village varies considerably based on the type of work performed. The types of private occupations, self-employed and honorarium are the side jobs that contribute significantly to the acceptance of fishing households from the nonagricultural sector. But overall the contribution of non-agricultural sector revenue is smaller when compared to revenue from other sectors.

\section{Total Fishermen Household Revenue}

Fishermen household income is the total income received by fisherman households from the fisheries sector, non-fisheries sector and non-agriculture sector within a certain period.

Table 3. Fisherman Household Reception in Sekunyit Village

\begin{tabular}{clcc}
\hline No & Type of Household Acceptance & Average (Rp) & Percentage (\%) \\
\hline 1 & Capture Fisheries Sector & $7,064,702.70$ & 82.08 \\
2 & Non-Fisheries Sector ( Rice) & $750,000.00$ & 8.71 \\
3 & Other Sectors & $791,891.89$ & 9.2 \\
\hline & total & $\mathbf{8 , 6 0 6 , 5 9 4 . 5 9}$ & $\mathbf{1 0 0}$ \\
\hline
\end{tabular}

Source: Primary Data Processed, 2018

Fishermen household revenue of fisheries catch is Rp. 7,064,702.70/ month or accounted for 82.08 percent of the total income of fishing households. Furthermore, revenue from the non- fisheries sector (rice farming) is Rp. $750,000.00$ per planting season. While household income from other sectors (non-agriculture) is Rp. 791,891.89 per month. Based on the distribution of 
these data it appears that the capture fisheries sector revenue provided the highest contribution to households for fishermen in Sekunyit Village. This shows that work as a fisherman is the main livelihood of the people there.

\section{Fishermen Household Expenditure Structure}

\section{Fisheries Sector Expenditures}

Fisheries sector spending is the value of the use upon the means of production, etc. incurred during the production process.

Based on Table 4 the biggest fisheries sector expenditure on the second point is the average variable cost of Rp. 1,376,527.03. Variable costs are costs that are used up in one use. The types of variable costs incurred such as fuel, ice cubes, cigarettes, bait and consumption. For their own fuel, fishermen use Pertamax.

Table 4. Fisheries Sector Expenditures

\begin{tabular}{clcc}
\hline No & \multicolumn{1}{c}{ Expenditures type } & Average (Rp) & Percentage (\%) \\
\hline 1 & Tool Depreciation Costs & $493,923.96$ & 16.64 \\
2 & Variable Cost & $1,376,527.03$ & 46.38 \\
3 & Labor costs & $157,212.16$ & 5.3 \\
4 & Sales fee & $708,783.78$ & 23.88 \\
5 & Maintenance costs & $231,252.86$ & 7.79 \\
\hline & total & $\mathbf{2 , 9 6 7 , 6 9 9 . 7 7}$ & $\mathbf{1 0 0}$ \\
\hline
\end{tabular}

Source: Primary Data Processed, 2018

While for fishermen bait using octopus, later octopus will be cut into pieces and put on the hook, in addition to octopus fishermen usually use bait from the results of the fish obtained from fishing.

\section{Expenditure in the Non-Fisheries Sector of Rice Farming}

Non-fisheries sector expenditures donated from rice farming. In this study, rice farming expenditure only calculates expenditure from the variable cost component and ignores the fixed cost component.

Table 5. Expenditures on Non-Fisheries Sector for Rice Farming

\begin{tabular}{clcc}
\hline No & \multicolumn{1}{c}{ Expenditures type } & Average (Rp) & Percentage (\%) \\
\hline 1 & Seed & $25,472.97$ & 7.65 \\
2 & Fertilizer & $72,128.38$ & 21.66 \\
3 & Pesticide & $12,695.95$ & 3.81 \\
4 & Labor (Planting and Harvesting) & $164,864.86$ & 49.5 \\
5 & Tractor Rentals & $42,554.05$ & 12.78 \\
6 & Land lease & $15,342.47$ & 4.61 \\
\hline \multicolumn{2}{c}{ total } & $\mathbf{3 3 3 , 0 5 8 . 6 8}$ & $\mathbf{1 0 0}$ \\
\hline
\end{tabular}

Source: Primary Data Processed, 2018

Based on Table 5, the biggest expenditure is on labor, which consists of labor for planting and harvesting. The small amount of costs incurred for nonfisheries sector expenditure is rice farming, because these costs are used once a year. Rice farming in Sekunyit Village in one year is only one planting season.

\section{Fishermen Household Food Expenditures}


Fisherman household expenditure is expenditure spent by each household during the research for one month. Fishermen household expenditure consists of food and non-food expenditure.

Based on Table 6, the total household expenditure of fishermen's household in Sekunyit Village per month is Rp. 554,100, 03, -. The highest average expenditure is for rice consumption for daily consumption, which is Rp. $211,891.89$ per month with a percentage of $38.24 \%$. Rice is a staple food as a source of carbohydrates.

Table 6. Fishermen Household Food Expenditures

\begin{tabular}{clcc}
\hline No & Types of Food Expenditures & Average (Rp) & Percentage (\%) \\
\hline 1 & Side dishes & $29,824.32$ & 5.38 \\
2 & Vegetables & $122,682.43$ & 22.14 \\
3 & Spices & $16,250.00$ & 2.93 \\
4 & Beverage Ingredients & $93,371.62$ & 16.85 \\
5 & Cooking oil & $21,945.95$ & 3.96 \\
6 & Rice & $211,891.89$ & 38.24 \\
7 & Chicken meat & $33,951.39$ & 6.13 \\
8 & Egg & $22,898.65$ & 4.13 \\
9 & Fruit & $1,283.78$ & 0.23 \\
\hline & Total & $\mathbf{5 5 4 , 1 0 0 . 0 3}$ & $\mathbf{1 0 0}$ \\
\hline
\end{tabular}

Source: Primary Data Processed, 2018

While the smallest expenditure is found in fruit consumption expenditure, which is Rp. 1,283.78, - with a percentage of $0.23 \%$. Fruit is a small percentage of vegetable protein and vitamins, because the villagers rarely consume fruit, this is also because the place to buy fruits is also far enough they have to buy to the market (in the city). By looking at this relatively small purchasing power, villagers reduce the types of expensive food such as chicken and eggs. Where for the price of one $\mathrm{kg}$ of chicken is $\mathrm{Rp}$. 40,000 and Rp. 2,000 per piece.

Food expenditure in Sekunyit Village is said to be low, due to their own side dishes such as fish they don't buy anymore and for their own fish consumption almost every day. According to Hans (2015), Humaidi, et al (2015). The higher the revenue, the portion of expenditure will shift from expenditure for food to non-food expenditure. The lower the portion of revenue spent on food ingredients and the higher the portion spent on non-food ingredients, the level of welfare increases.

\section{Fishermen Household Non-Food Expenditures}

Non-food expenditure needs are other basic needs for fishing households such as body care, fuel, electricity, education and other needs.

From Table 7 shows that the average household expenditure of fishermen for non-food expenditure per month is Rp. 431,878, 38, -. Each fisherman household has different expenses to meet their needs. Household food expenditure fisherman in the village of Sekunyit larger than the nonfood expenditure, at the same time fishermen household can be said to have not been prosperous. According to Arida et al, (2015), Nasution (2007), Hans (2015) stated that the proportion of food expenditure that is higher than the proportion of non-food expenditure 
shows that fishermen households are still not prosperous.

\section{Fishermen Household Expenditures}

Fishermen household xpenditure is the total expenditure spent by each fisherman household in one month, both expenditures from the fisheries sector, non-fisheries and non-agricultural sectors (food and non-food).

Table 7. Fishermen Household Non-Food Expenditures

\begin{tabular}{clcc}
\hline No & Types of Food Expenditures & Average (Rp) & Percentage (\%) \\
\hline 1 & Body Care & $34,209.46$ & 7.92 \\
2 & Fuel & $67,439.19$ & 15.62 \\
3 & Electricity & $95,986.49$ & 22.23 \\
4 & Communication & $23,189.19$ & 5.37 \\
5 & Education & $71,324.32$ & 16.51 \\
6 & Credit installments & $121,486.49$ & 28.13 \\
7 & Social activities & $18,243.24$ & 4.22 \\
\hline & total & $\mathbf{4 3 1 , 8 7 8 . 3 8}$ & $\mathbf{1 0 0}$ \\
\hline
\end{tabular}

Source: Primary Data Processed, 2018

Table 8. Total fishermen household expenditure in Sekunyit Village

\begin{tabular}{clcc}
\hline No & Type of Household Expenditures & Average (Rp) & Percentage (\%) \\
\hline 1 & Capture Fisheries Sector & $2,967,699.77$ & 69.24 \\
2 & Non-Fisheries Sector for Rice Farming & $333,058.68$ & 7.77 \\
3 & Non Agriculture (Food and Non Food) & $985,060.81$ & 22.98 \\
\hline & total & $\mathbf{4 , 2 8 5 , 8 1 9 . 2 6}$ & $\mathbf{1 0 0}$ \\
\hline
\end{tabular}

Source: Primary Data Processed, 2018

Expenditure fisheries catch is the amount of the costs incurred to finance the activities of fishermen at sea. Expenditu renon fisheries sector is the cost incurred by fishermen in the farming of rice per cropping season. Whereas non-agricultural expenditure is calculated based on food expenditure and non-food expenditure of fishermen households. From the research, the largest expenditure in the fisheries sector contained in the fisheries sector fishing is Rp. 2,967,699.77, or accounted for 69.24 percent of the total fishermen household expenses each month.

\section{CONCLUSIONS AND SUGGESTIONS}

\section{Conclusion}

1. The structure of fishermen household acceptance comes from the capture fisheries sector, non-fisheries sector (lowland rice farming) and nonagricultural sectors (entrepreneurs, laborers, coolies, honorariums, stalls, private sector). The amount of revenue from the capture fisheries sector is Rp. 7,064,702.70 per month, non-fisheries sector (lowland rice) of Rp. 750,000.00, - per month and of the non-agricultural sector amounted to Rp. 791,891.89 per month.

2. Fishermen household expenditure structure consists of capture fisheries sector, non-fisheries sector (lowland rice) and non-agriculture sector (food and non-food sector). The amount of expenditure for the capture fisheries sector is Rp. 2,967,699.77 per month, non-fisheries sector (lowland rice) of Rp.333,058.68, - per month and of the non-agricultural sector amounted to 
Rp. 554,100.03 per month (food expenditure) and non-food expenditure of Rp. 431,878.38 per month.

\section{Suggestion}

The role of side jobs becomes an alternative for fishermen to increase household income. Work outside the capture fisheries sector is one of the fishermen's businesses to meet their household needs if at any time bad weather continues which results in fishermen being unable to go to sea.

\section{REFERENCES}

Arida, A., Sofyan, S., \& Fadhiela, K. 2015. Analysis of household food security based on the proportion of food expenditure and energy consumption (Case Study of Farmer Households Participating in the Independent Food Village Program in Indrapuri District, Aceh Besar District). Journal of Agrisep, 16 (1), 20-34.

Zargustin, D. L. Siswati and Mufti. 2015. Strata of land mastery and income of rice field farming and its relationship with work time allocation outside Farming. Agribusiness Journal. 17(1) : 1 - 9

Dwi, S., Rizal, A. and Donny, JP 2016. Analysis of Fixed and Bubu Net Gills Fishermen Revenue in Membalong District, Belitung Regency. Journal of Marine Fisheries. Vol. VII No.2 (9-13)

Fauziyah, E., S. Hartoyo, N. Kusnadi dan S. U. Kuntjoro. 2010. Analisis Produktivitas Usahatani Tembakau Di Kabupaten Pamekasan. Jurnal Organisasi dan Manajemen, Volume 6, Nomor 2, September 2010, 119-131

Khanisa F. A. and Sudrajat. 2012. Analysis of Tobacco Farmer Income in Menggoro Village, Tembarak District, Temanggung Regency. Jurnal Bumi Indonesia Volume 1, Number 3, 2012

Hans SM Salakory. 2015. Analysis of Fishermen Household Welfare Level Based on Exchange Rate (NTN) in Sowi IV Village, Manokwari Regency. Management Study Program STIE Mah-Eisa Manokwari. Journal Volume 2, Number 2 Pages: 45 - 54

Humaidi, E., Z, Amin and N, Suryati. 2015. Rubber Farmer Household Expenditure in Binjai Village, Muara Kelingi District. Agribusiness Study Program, Faculty of Agriculture, Musi Rawas University. Lubuku. SOCIETA IV1: $54-58$

Jahasiel Liasta Tarigan, Salmiah, and Lily Fuiziah (2013). Feasibility Analysis of Smallholder Tobacco Farming (Case Study: Batukarang Village, Payung District, Karo District) Journal on Social Economics of Agriculture and Agribusiness Vol 2, No. 11

Kustiawati Ningsih, Herman Felani, Halimatus Sakdiyah (2015). Performance of Farming and Organic Dragon Fruit Marketing. Agrieconomics, October, 2015e ISSN 2407-6260 Volume 4, Number 2

Manalu, A. S., B. Sumantri and B. S. Priyono, 2018. Income Based on the Status of Tobacco Farming and Marketing. J. Agrisep. 17 (1): 63-78.

Mawardati. 2015. Analysis of the factors that influence areca nut farming income in Sawang sub-district, North Aceh district. J. Agrisep. 16 (1): 61-65.

Nasution, KI 2007. Smoking behavior in adolescents. 
http://library.usu.ac.id. Accessed May 22, 2018

Putri, E.A., A. Suwandari and J.A. Ridjal. 2015. Analysis of income and cost efficiency of the Maesan 2 tobacco farm in Bondowoso district. J.SEP. 8 (1): 64-69.

Soekartawi. 2003. Economic Theory of Production. PT. Raja Grafindo Persada. Jakarta. 